\title{
Heard any good books lately?
}

'Welcome,' says the London Observer of 2 Feb 86, 'to the brave new world of audio publishing, a phenomenon which is changing America's reading habits. Across the nation, in coin launderettes, supermarket queues, traffic jams, trains, cars and buses, Americans are listening to books on tape.

Not that the Americans are alone. In Britain, audio tapes have been available for a number of years through the record trade, on offer from companies like Associated Book Publishers, who have an aural Wind in the Willows and sold to Thorn EMI the rights to such audioclassics as The Hitchhiker's Guide to the Galaxy. In the US, however, the stakes are higher and the markets larger. 1985 returns doubled the 1984 gross sales figure of $\$ 50$ million. As the Observer

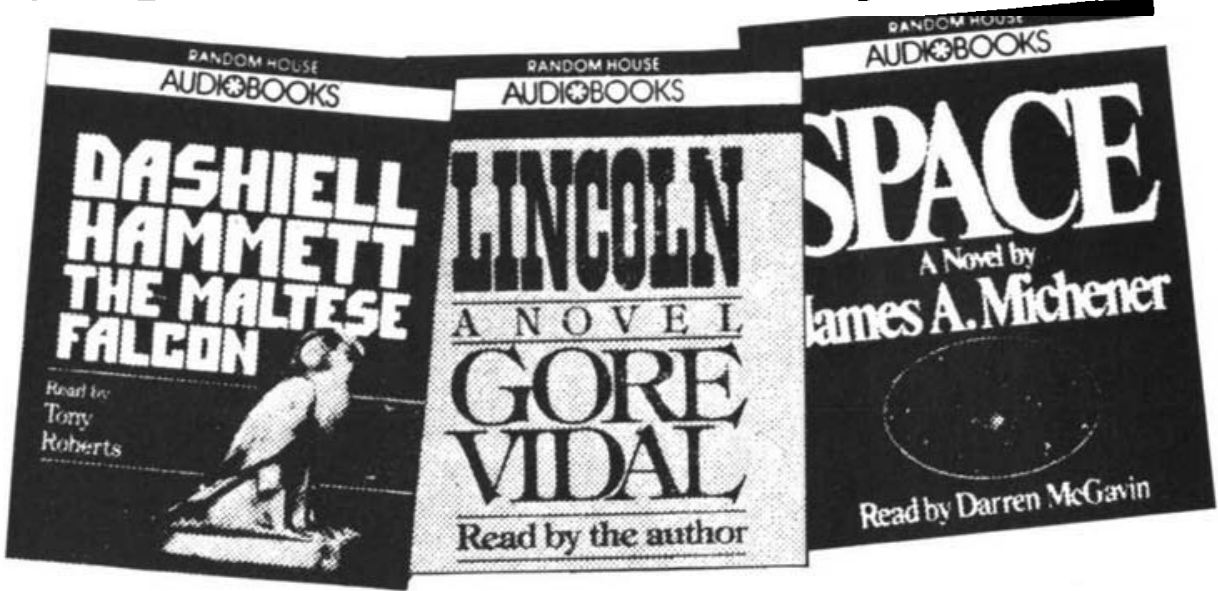

notes; this makes audio-books a kind of 'Kentucky Fried Literature', where Tolstoy's War and Peace can sit on the shelf

\section{Last stand or first strike?}

'Mitterrand leads last stand against English invasion,' ran the headlines in The Times of London (18 Feb 86). 'Mitterrand urges Francophone states to counter threat to their identity,' said the International Herald Tribune on the same date, while The Guardian (21 Feb) added: 'Vive la France in scientific terms.'

The references were to a summit meeting at the palace of Versailles near Paris, where the French president François Mitterrand addressed representatives of nearly forty countries that have strong French-speaking communities or traditions in which French figures importantly. Words were not minced in or around the summit, as the following comments show:

- 'In his recent book on French foreign policy, M Mitterrand spoke of his concern at the retreat of the French language in the face of the rapid spread of English, and complained of the "irritating habit of certain of our diplomats, civil servants, and even politicians to speak in a language other than their own" when abroad.' (The Times)

- "Must we give orders to our computers in English?" $M$ Mitterrand asked recently at a meeting of the Académie Française, the body founded in 1635 to unify and protect the French language. "The nation that produces the Ariane [rocket] has not the right to lose its tongue."' (IHT)

- 'President Mobutu of Zaire said at the final session on Wednesday that ... the idea of a French-speaking world community had now passed beyond the stage of folklore.' (The Guardian)

- 'Three Canadians are attending the conference as equal representatives: $\mathrm{Mr}$
Mulroney [the Prime Minister], Premier Robert Bourassa of Quebec, and Premier Richard Hatfield of New Brunswick. In the past, Canadian prime ministers refused to grant Quebec's envoys equal rank at such conferences.' (IHT)

- 'Le Monde commented yesterday that sooner or later French people would realise that the French-speaking dimension was an original way for a particular group of countries to resist the "banalisation" or growing uniformity of the world. The paper quoted a Quebec representative who observed that the French media had given less space to the summit than to an exhibition of lingerie.' (The Guardian)
No one foresaw it, least of all the Queen of Crime herself, in 1952 when it all started. A modest run for her latest mystery play to grace the London stage - that was all Agatha Christie or anybody else expected.

Thirty-three years later, however, The Mousetrap is still playing to full houses. It has become both a national British theatrical phenomenon - the longest running play in history - and an institution of the English language. Tourists visiting London routinely and with enthusiasm reserve tickets for the show. There was a champagne celebration for a thousand thespians and friends in London in March, to mark the play's remarkable durability. President Ronald Reagan sent a telegram of congratulations which concluded: 'We wish you constant beside Susann's Valley of the Dolls (read by Juliet Mills). 'We don't cut a word, not even the rude ones,' says Duvall Hecht, president of Books on Tape, which produces such works.

'Audio-book centers' are taking up more space in conventional bookstores around Los Angeles and comparable localities. There one can pick up anything from two 90-minute cassettes of Gore Vidal reading from his novel Lincoln (Random House Audiobooks, \$14.95) to a 20-minute Workout for Firmer Fannies by Susan Rasmussen Englander (Sound Solution, \$6.95). The hype fits the product. An ad in the New York Times promotes the Random House tapes as 'bestsellers that read themselves aloud', while the cover-blurb of the Rasmussem tape runs: 'Firm up, trim down, lift sags and improve the overall shape and definition of your fanny.'

Clearly, we have not yet heard the last word on audio-lit.

\section{A third of a century and still going...}

success and another 33 years of laughter and suspense.'

The play is a classic 'whodunnit', has provided employment for 205 actors since it opened, and been seen by some seven million theatre-goers. 'The Mousetrap is indestructible,' says Sir Richard Attenborough, who starred in the original show. Certainly, such institutions have a way of perpetuating themselves, putting The Mousetrap in the mythology of English alongside the Oxford and Webster dictionaries, Churchill's speeches, the Shakespearean canon, Dickens's novels and the BBC World Service. Sir Richard and President Reagan - each with a share of theatrical instinct - could be right: Christie's play could still be bringing in full houses well into the 21 st century. 